Jurnal Pendidikan Biologi 7 (2) (2018) $117-126$
$\begin{gathered}\text { Jttp://jurnal.unimed.ac.id/2012/index.php/JPB } \\ \text { eISSN: 2502-3810pISSN: 2086-2245 }\end{gathered}$

\title{
Hubungan Metakognitif, Kemampuan Berpikir Kritis, Bimbingan Orang Tua dan Guru tentang Kesehatan Reproduksi dengan Persepsi Perilaku Seksual Siswa SMA Se-Kota Medan
}

\author{
Alfi Sapitri ${ }^{1^{*}}$, Elly Djulia $^{2}$, Herbert Sipahutar ${ }^{2}$ \\ ${ }^{1}$ Program Studi Farmasi, Universitas Sari Mutiara \\ ${ }^{2}$ Program Studi Pendidikan Biologi, Universitas Negeri Medan \\ *Korespondensi: alfi.syahfitri@gmail.com
}

\begin{abstract}
This research intended to identify: (1) Student metacognition about reproduction health, (2) student critical thinking skill about reproduction health; (3) Student perception of sexual behaviour, (4) Parents' and teachers' guidance about reproduction health, (5) Teachers' guidance about reproduction health, (6) The correlation among metacognitive, critical thinking, parents' and teachers' guidance about reproduction health into perception of sexual behaviour. This correlation study was conducted at Senior high schools in district Medan, North Sumatra Indonesia at 2013 academic year. Research instruments consist of metacognitive knowledge, metacognitive skill, critical thinking, parents' and teachers' guidance, and student perception of sexual behaviour that had been tested for validation, reliability, differential index and difficulty level. Data were analyzed through applied correlation analysis by using SPSS 21.0 for windows. The result of this study indicated that: (1) student metacognitive knowledge are moderately categorized as urban and rural while metacognitive skill are highly categorized for urban and rural; (2)student's critical thinking are classified as moderate in urban and rural; (3) the student's perception of sexual behaviour are moderate urban and rural;(4) parents' guidance contributed moderately in urban and rural; (5) teachers' guidance contributed moderately in urban and lowly in rural; (6) there is significant correlation between student perception of sexual behaviour and metacognition, critical thinking skill, parents' and teachers' guidance about reproduction health with Sig $0,049<0,05$.
\end{abstract}

Keywords: Critical Thinking Skill, Parents' Guidance and Teachers' Guidance, Science Metacognition, Student Perception of Sexual Behaviour.

\section{PENDAHULUAN}

Remaja dalam bahasa Latin disebut adolescence yang artinya tumbuh atau tumbuh untuk mencapai kematangan (Ali, 2009). Masa remaja adalah masa transisi yang ditandai oleh adanya perubahan perubahan fisiologis pada manusia. Hal ini dijelaskan oleh Sarwono (2011) pada masa remaja, organ-organ seks laki-laki dan perempuan telah mulai berfungsi, dan menyebabkan remaja sensitif terhadap rangsangan atau godaan seksual".

Jean Pigeat dalam McCulley, (2010) mengemukakan perkembangan kognitif anak pada masa pubertas berada pada 
periode terakhir dan tertinggi dalam tahap pertumbuhan periode formal (period offormal operations), remaja pada periode ini sudah memiliki pola pikir sendiri dalam usaha memecahkan masalah-masalah yang kompleks dan abstrak sehingga pada masa pubertas, remaja memiliki kemampuan metakognitif yang sudah berkembang sangat baik. Metakognisi (metacognition) merupakan suatu istilah yang diperkenalkan oleh Flavell pada tahun 1976. Menurut Flavell, sebagaimana dikutip oleh Livingston (1997), metakognisi terdiri dari pengetahuan metakognitif (metacognitive knowledge) dan pengalaman atau regulasi metakognitif (metacognitive experiences or regulation). Metakognisi merupakan bagian dari proses perencanaan (planning), pemantauan (monitoring), dan evaluasi (evaluating) (Ikayanti dan Sugiarto. 2012). Miranda dan Yula (2010) menyatakan pengetahuan metakognitif akan membentuk perilaku siswa dalam meningkatkan kesadaran mengenai proses berpikir dan pembelajaran yang berlaku.

Kasus mengenai perilaku seksual remaja menjadi lebih mengkhawatirkan dari waktu ke waktu seperti seks bebas, pernikahan dini, penularan penyakit menular seksual dan aborsi. Ini disebabkan oleh perubahan persepsi perilaku pacaran pada remaja disertai dengan pola perilaku seksual mulai dari berciuman, petting dan intercourse (Hurlock dalam Raza, Adil \& Ghayas, 2008). Penelitian Pusat kajian dan Perlindungan Anak di Medan tentang perilaku seksual remaja di 10 SMA/SMK di Sumatera Utara (2000) menunjukkan sudah berpelukan $57,2 \%, 9,4 \%$ berciuman, $10,5 \%$ petting, 23\% hubungan seksual dengan pacar $86,1 \%$, dengan teman dekat $5,4 \%$ dengan orang yang dikenal $2,7 \%$ dan dengan tetangga $0,3 \%$. Hasil surveilans terpadu biologi dan perilaku (2011) di enam kota-kota di Indonesia bahwa hanya 16\% responden memiliki pengetahuan tentang kesehatan reproduksi, 15\% menggunakan kondom, 5\% memahami tentang penyakit kelamin dan 95\% mengetahui seksual berkontribusi kehamilan.

Saat ini pacaran menjadi suatu kebiasaan di kalangan remaja dan yang tidak memiliki pacar akan dikatakan kuno (Kusmiran, E. 2011). Berbagai faktor mempengaruhi perilaku tersebut salah satunya adanya persepsi bahwa hubungan seks merupakan cara mengungkapkan cinta, sehingga demi cinta, seseorang merelakan hubungan seksual dengan pacar sebelum nikah (Muspiroh, 2007). Maka perlu dilakukan penelitian mengenai "Hubungan metakognitif, kemampuan berpikir kritis, bimbingan orang tua dan guru tentang kesehatan reproduksi dengan persepsi perilaku seksual siswa SMA".

\section{METODE PENELITIAN}

Penelitian ini dilaksanakan di SMA Negeri dan Swasta yang berada di kota dan pinggiran kota Medan. Jenis penelitian adalah penelitian exs post facto. Sampel dalam penelitian ini diambil dengan menggunakan teknik cluster random sampling dengan jumlah responden 394 siswa yang berasal dari kelas XI IA.

Data penelitian diperoleh dengan mengadakan tes tertulis kepada siswa berupa tes metakognitif, kemampuan berpikir kritis tentang kesehatan reproduksi serta angket persepsi perilaku seksual dan menyebarkan angket bimbingan kepada orang tua dan guru. Data yang telah diperoleh kemudian diolah dengan program SPSS versi 21. Teknik analisis data yang digunakan adalah statistik deskriptif dan inferensial (Arikunto, 2009). 
HASIL PENELITIAN

Hasil uji data dengan statistik deskripsi tes metakognitif yang terdiri dari tes pengetahuan metakognitif siswa tentang kesehatan reproduksi (Gambar 1), keterampilan metakognitif siswa tetang kesehatan reproduksi (Gambar 2), kemampuan berpikir kritis siswa tentang kesehatan reproduksi (Gambar 3), bimbingan orang tua tentang kesehatan reproduksi (Gambar 4), Bimbingan Guru tentang kesehatan reproduksi (Gambar 5), dan persepsi perilaku seksual siswa (Gambar $6)$.

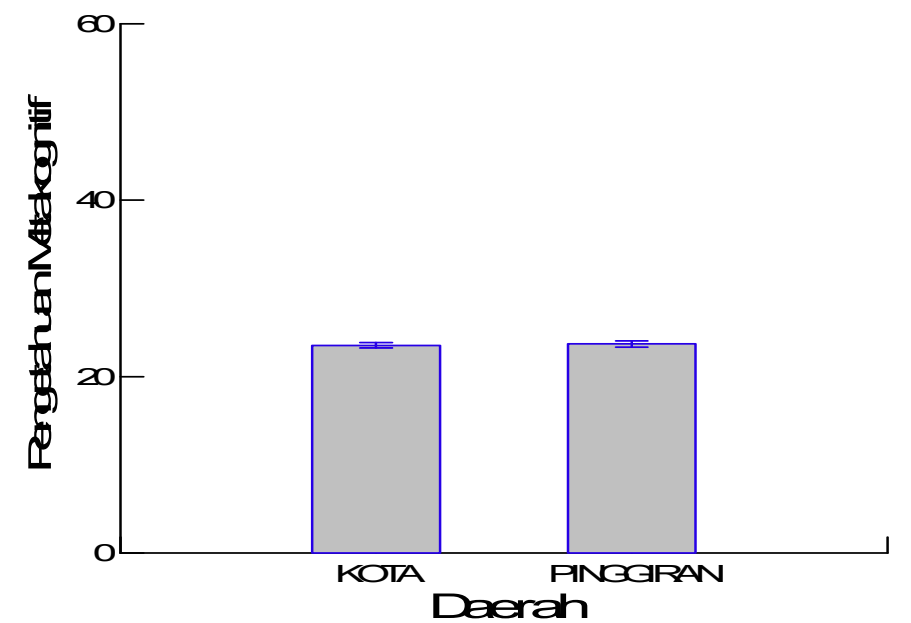

Gambar 1. Tingkat Pengetahuan Metakognitif Siswa di daerah kota medan (x) 23,55; SD =4,48 dan pinggiran $(\mathrm{x})$ ) 23,67 ; $\mathrm{SD}=4,56$ (Skor $0-60$ ).

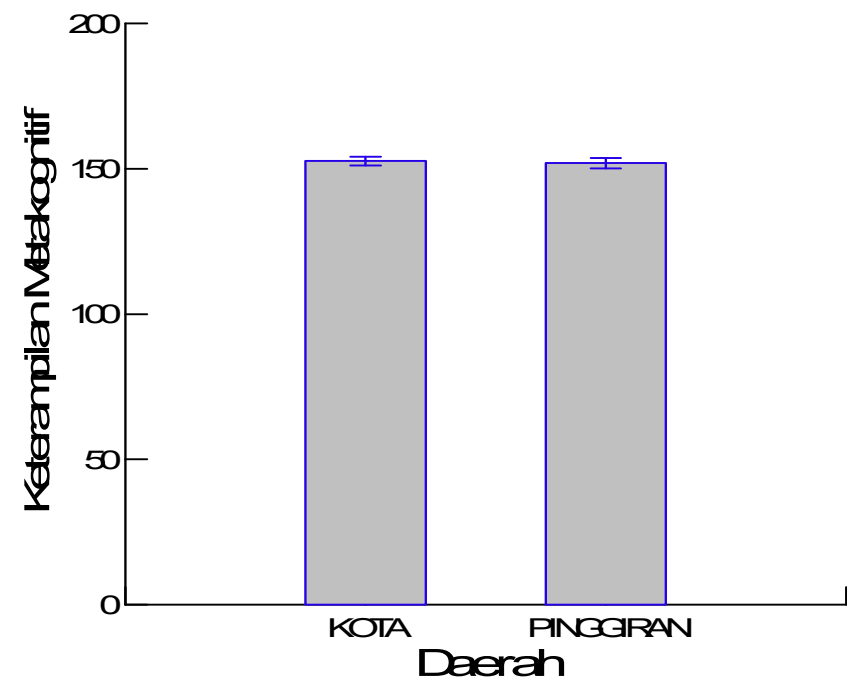

Gambar 2. Tingkat keterampilan metakognitif siswa di daerah kota medan $(x \overline{)} 152, \mathrm{SD}=21,59$ dan pinggiran $(\mathrm{x})$ 151,86; SD = 24,48 (Skor $0-200)$. 


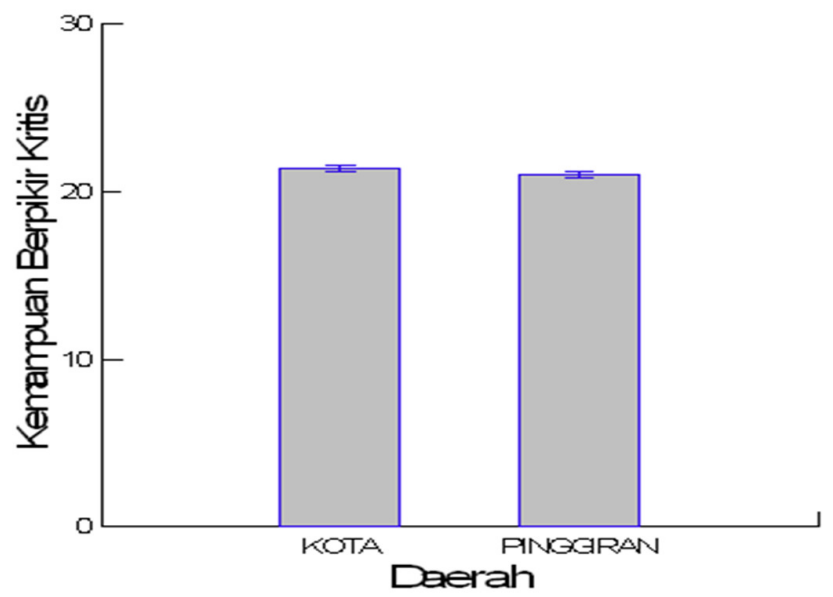

Gambar 3. Kemampuan berpikir kritis siswa di daerah kota medan (x $)$ 21,38; $\mathrm{SD}=2,72$ dan pinggiran (x) 21,06; SD = 2,49 (Skor 0 - 30).; SD = 2,49 (Skor 0 - 30).

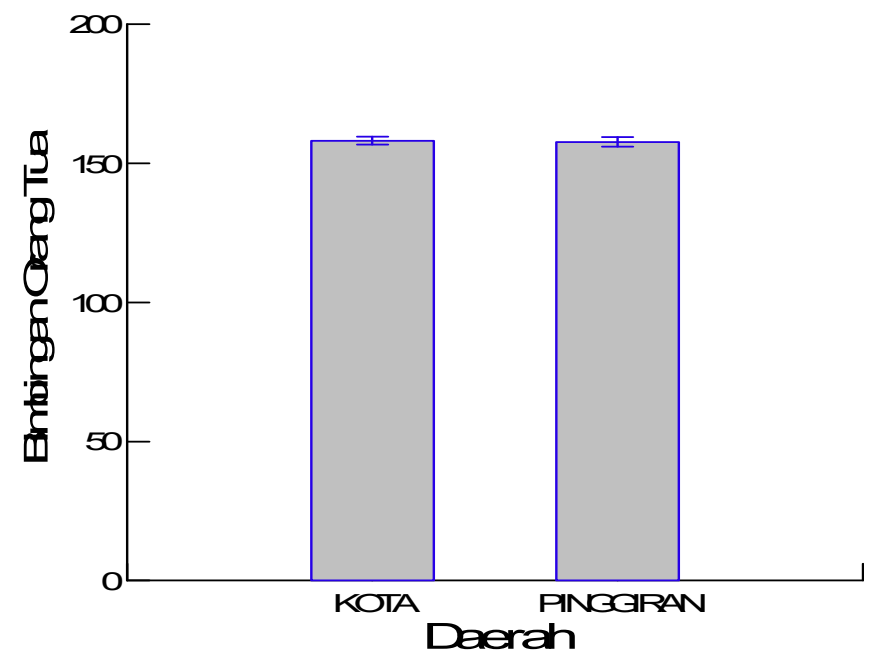

Gambar 4. Bimbingan orang tua siswa di daerah kota medan (x $)$ 158,24; $\mathrm{SD}=20,72$ dan pinggiran (x) 157,$58 ; \mathrm{SD}=23,56$ (Skor 0 - 200).

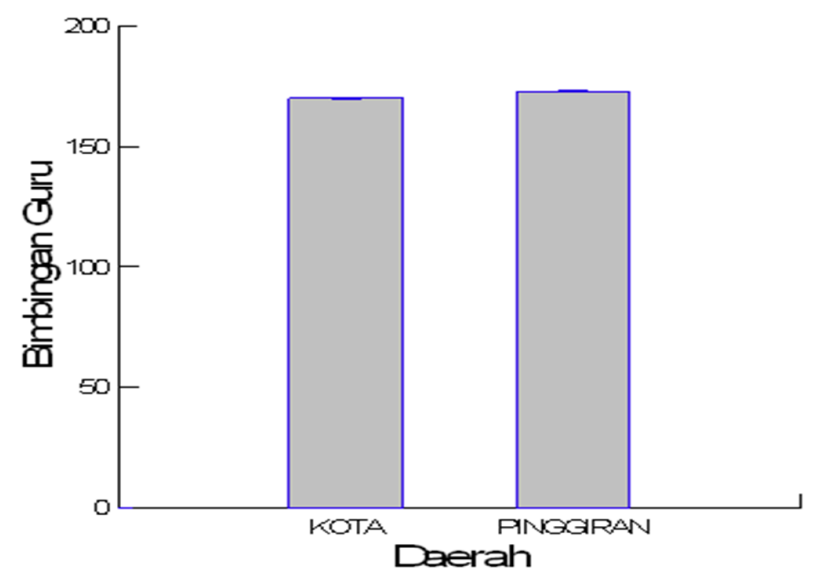

Gambar 5. Bimbingan guru di daerah kota medan $(\mathrm{x})$ 173,50 ; SD = 7,50dan pinggiran(x $)$ 172,25 ; $\mathrm{SD}=4,79$ (Skor $0-200)$.; $\mathrm{SD}=2,49$ (Skor $0-30)$. 


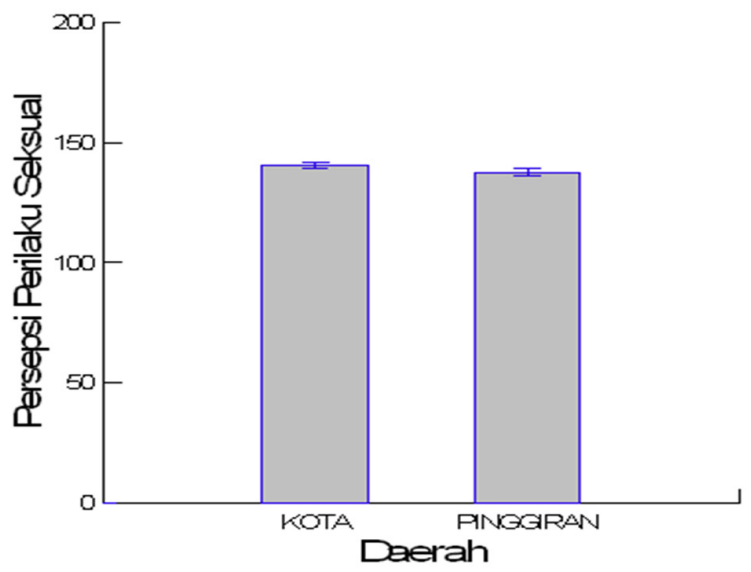

Gambar 6. Persepsi perilaku seksual siswa di daerah kota medan (x $)$ 140,31; SD $=20,45$ dan pinggiran $(\mathrm{x})$ 137,68; $\mathrm{SD}=21,33$ (Skor $0-200)$. $\mathrm{SD}=2,49$ (Skor $0-30$ )

Pengetahuan metakognitif siswa tentang kesehatan reproduksi di Kota dan pinggiran dikategorikan sedang, dengan nilai uji $\mathrm{T}$ tidak terdapat perbedaan yang signifikan di Kota dan di pinggiran (Gambar 1). Keterampilan metakognitif siswa di kota dan pinggiran dikategorikan tinggi, dengan nilai uji $\mathrm{T}$ tidak terdapat perbedaan yang signifikan di Kota dan pinggiran (Gambar 2).

Kemampuan berpikir kritis tentang kesehatan reproduksi di Kota dan pinggiran dikategorikan sedang dengan nilai uji $\mathrm{T}$ tidak terdapat perbedaan yang signifikan di Kota dan pinggiran (Gambar 3). Bimbingan orang tua di Kota dan pinggiran dikategorikan sedang, dengan nilai uji $\mathrm{T}$ tidak terdapat perbedaan yang signifikan di Kota dan pinggiran (Gambar 4). Bimbingan guru tentang kesehatan reproduksi di Kota dikategorikan sedang dan di daerah pinggiran dikategorikan rendah, dengan nilai uji $\mathrm{T}$ tidak terdapat perbedaan yang signifikan di Kota dan pinggiran (Gambar 5). Persepsi perilaku seksual siswa di daerah Kota dan pinggiran dikategorikan sedang, dengan nilai uji $\mathrm{T}$ tidak terdapat perbedaan yang signifikan di Kota dan pinggiran (Gambar 6).

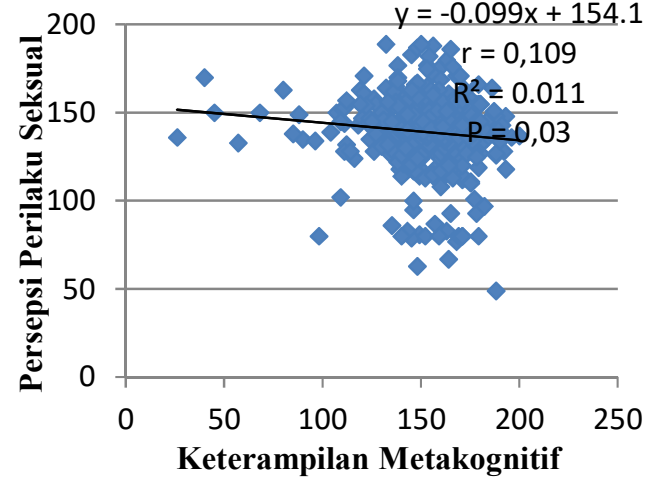

Gambar 7. Hubungan persepsi perilakuseksual dengan pengetahuan metakognitif

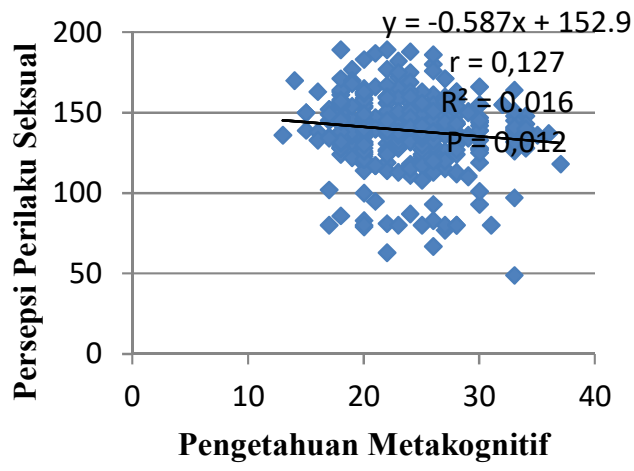

Gambar 8. Hubungan persepsi perilaku seksual dengan keterampilan metakognitif 


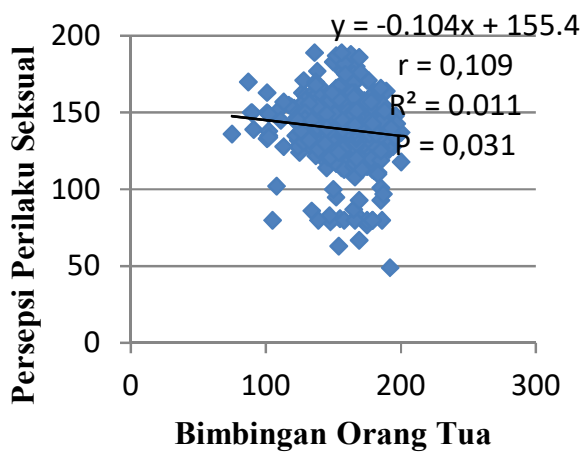

Gambar 9. Hubungan persepsi perilaku seksual dengan kemampuan berpikir kritis

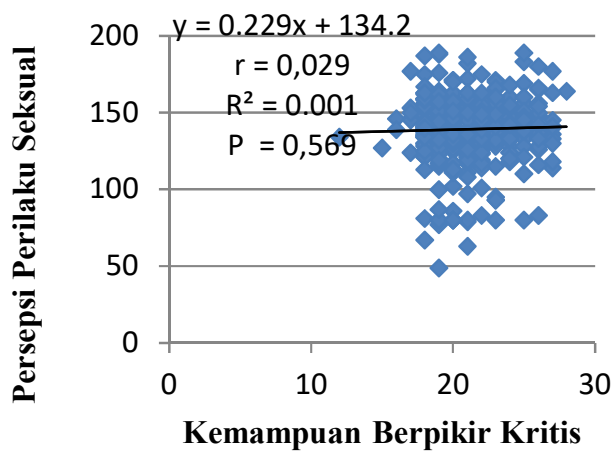

Gambar 10. Hubungan persepsi perilaku seksual dengan bimbingan orang tua

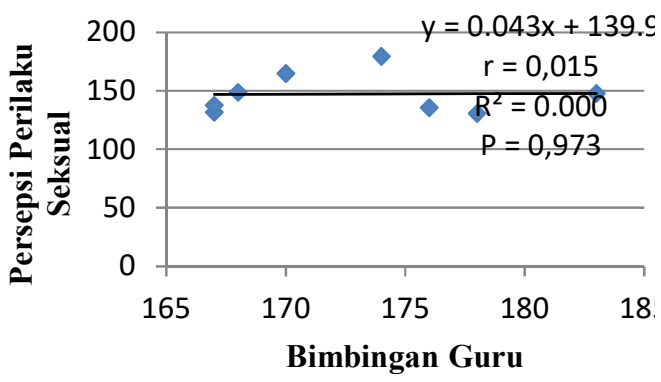

Gambar 11. Hubungan persepsi perilaku seksual dengan bimbingan guru

Hasil analisis regresi berpikir kritis tidak memiliki hubungan yang positif dengan persepsi perilaku seksual siswa dengan Sig $0.569>0,05 ; r=0.029$. kontribusi $0,1 \%$; dan $\mathrm{R} 2 \mathrm{x} 2 \mathrm{y}=0,001$. Ini berarti bahwa hubungan berpikir kritis tentang kesehatan reproduksi dikategorikan rendah dengan persepsi perilaku seksual siswa (Gambar. 9). Analisis regresi bimbingan orang tua memiliki hubungan positif dengan persepsi perilaku seksual siswa dengan Sig 0,031<0,05; $r=$ 0.109 , dan memberikan kontribusi $1,2 \%$ dan $\mathrm{R} 2 \mathrm{x} 3 \mathrm{y}=0.012$. Itu berarti bimbingan orang tua tentang kesehatan reproduksi dikategorikan rendah dengan persepsi perilaku seksual siswa (Gambar. 10). Analisis regresi bimbingan guru tidak memiliki hubungan yang positif dengan persepsi perilaku seksual siswa dengan Sig $0.973>0,05 ; \mathrm{r}=0.015$, dan memberikan kontribusi $0 \%$ dan $\mathrm{R} 2 \mathrm{x} 4 \mathrm{y}=0,000$. Itu berarti bimbingan guru tentang kesehatan reproduksi dikategorikan rendah dengan persepsi perilaku seksual siswa (Gambar. 11).

Hasil uji analisis korelasi dari data pengetahuan metakognitif, keterampilan metakognitif, kemampuan berpikir kritis, bimbingan orang tua dan guru secara bersama-sama dengan persepsi perilaku seksual siswa, dapat diketahui harga $\mathrm{r}=$ 0,168 , yang berarti memiliki hubungan positif antara tingkat pengetahuan metakognitif, keterampilan metakognitif, kemampuan berpikir kritis, bimbingan orang tua dan guru dengan persepsi perilaku seksual siswa cukup kuat dengan nilai Sig $0,049<0,05$ maka hipotesis nihil $\left(\mathrm{Ho}_{6}\right)$ yang menyatakan tidak terdapat hubungan yang signifikan antara tingkat pengetahuan metakognitif, keterampilan metakognitif, kemampuan berpikir kritis, bimbingan orang tua dan bimbingan guru secara bersama-sama dengan persepsi perilaku seksual siswa ditolak, sehingga hipotesis alternatif $\left(\mathrm{Ha}_{6}\right)$ nya diterima.

\section{PEMBAHASAN}

Berdasarkan data hasil penelitian yang dilakukan di SMA se-Kota Medan berjumlah 394 responden memiliki pengetahuan metakognitif yang baik tentang kesehatan reproduksi termasuk peren- 
canaan, pemantauan dan mengevaluasi pemahaman tentang pengaruh faktor kesehatan reproduksi, menstruasi, gangguan kesehatan, kehamilan, menopause dan kelainan penyakit. Sementara keterampilan metakognitif lebih baik di perkotaan daripada pinggiran ditunjukkan oleh kemampuan siswa dalam menerapkan pengetahuan baru pada sistem reproduksi dalam merancang pembelajaran. Flavel (1979) menggambarkan orang yang memiliki pengetahuan metakognitif yang baik akan menggunakan pengetahuan yang diperoleh, dan pengetahuan menunjukkan keterampilan dan strategi yang akan digunakan dalam pembelajaran dan dalam kehidupan sehari-hari. Slavin (2008) menjelaskan, siswa yang menerapkan strategi dalam memproses informasi baru untuk mengaktifkan pengetahuan awal belajar meningkatkan pemahaman mereka tentang beberapa jenis bahan dan membantu mereka dalam menilai pemahaman mereka sendiri.

Keterampilan metakognitif yang dimiliki siswa baik yang di kota dan dikategori tinggi, hal ini dapat diindikasi karena siswa sudah bisa mengembangkan dan mengelola diri sendiri dalam belajar seperti (1) Mengidentifikasi gaya belajar yang paling cocok untuk diri sendiri (visual, auditif, kinestetik, deduktif, atau induktif); (2) Memonitor dan meningkatkan kemampuan belajar (membaca, menulis, mendengarkan, mengelola waktu, dan memecahkan masalah); (3) Memanfaatkan lingkungan belajar secara variatif (Dhanapala, K. 2010).

Keterampilan berpikir kritis siswa perkotaan dan pinggiran menunjukkan bahwa siswa tidak menerapkan berpikir kritis untuk mendorong kreativitas dan menghasilkan pembelajaran dengn pemecahan masalah dalam pembelajaran di sekolah dan kehidupan sehari-hari. Ini bertentangan dengan Salam (2004) bahwa penalaran ilmiah, berpikir kritis menghasilkan belajar yang lebih responsif dan aktif. Demikian juga, Santrock (2008) mengatakan bahwa siswa yang belajar untuk berpikir secara mendalam memikirkan dampak dari setiap tindakannya sementara siswa yang berpikir dangkal tidak mempertimbangkan dampak dari tindakan, bahkan seringkali lebih banyak berbicara daripada berbuat. Fisher (2009) menjelaskan keterampilan berpikir kritis digambarkan sebagai suatu proses aktif yang melibatkan peran metakognisi (berpikir tentang berpikir sendiri).

Bimbingan orang tua kepada anak-anak hubungannya rendah dengan pembentukan sikap anak-anak dalam perilaku seksual sehingga dikategorikan sedang. Ada sedikit anak yang melakukan perilaku seksual menyimpang dengan melakukan hubungan seksual. Hal ini disebabkan pendidikan kesehatan reproduksi masih sangat tabu untuk dibahas oleh masyarakat Indonesia, sebagai penganut budaya timur seperti yang dilakukan orang tua mereka. Bimbingan orang tua (anak usia dini, remaja, dewasa, bimbingan orangtua, dan pendidikan agama) untuk perilaku seksual remaja sangat penting karena berperan dalam melindungi, mendidik, dan memberikan contoh bimbingan kepada anak-anak untuk mengenal, memahami, dan akhirnya mampu menerapkan perilaku yang sesuai dengan nilai-nilai dan norma-norma yang ada dalam masyarakat. Aspya, et al. (2007) mengatakan bahwa remaja jauh lebih kecil kemungkinannya untuk melakukan hubungan seksual jika orang tua mereka mengajarkan mereka untuk mengatakan tidak, menetapkan aturan yang jelas, berbicara tentang apa yang benar dan salah untuk menunda aktivitas seksual. Morawska, et al. (2015) menyebutkan bahwa dengan mengajarkan tentang perilaku seksual dan menghubungkan pencegahan pelecehan 
seksual anak akan mendorong rasa positif diri dan si anak akan menjaga kehormatan diri.

Bimbingan guru juga memberikan kontribusi yang baik pada perkotaan dan lebih rendah di pinggiran meskipun tidak ada perbedaan yang signifikan antara perkotaan dan pinggiran. Guru berkontribusi dalam 1) merancang rencana pembelajaran, 2) media pembelajaran dan sumber, 3) mendidik siswa, 4) guru memberikan nasihat dan 5) pencegahan gangguan perilaku seksual. Guru selain melaksanakan pengajaran untuk mata pelajaran, guru juga berperan dalam mendidik, mengarahkan, memelihara dan memberikan contoh perilaku yang baik sehingga dapat mencegah siswa melakukan perilaku seksual menyimpang. Miyakado (2013) menjelaskan pemberian pendidikan seks kepada siswa dipandang sebagai sangat penting untuk membuat mereka mengerti manfaat dan merugikan aktivitas seksual. Mkumbo \& Tungaraza (2007) menyatakan bahwa menurut penelitian, pendidikan seks dapat membawa lebih banyak manfaat kepada mahasiswa dan masyarakat pada umumnya.

Metakognisi, berpikir kritis, bimbingan orangtua dan guru tentang kesehatan reproduksi mempengaruhi persepsi siswa tentang perilaku seksual. Pengetahuan dan pemahaman berasimilasi melalui proses berpikir kritis sehingga manusia sadar dapat bertindak dalam perilaku yang lebih bertanggung jawab (Bahri, 2008). Meskipun penelitian ini menunjukkan bahwa metakognisi siswa berkorelasi positif dengan persepsi siswa tentang perilaku seksual, tetapi tidak untuk kemampuan berpikir kritis. Mnguni, Abrie \& Ebersohn (2015) menyatakan dalam penelitiannya bahwa jenis pengetahuan yang dapat mempengaruhi perilaku dan peningkatan pengetahuan HIV/AIDS akan aman dalam berperilaku. Veenman et. al, (2009) menyatakan hubungan antara pengetahuan dan keterampilan metakognitif terhadap perkembangan persepsi anak sangat berpengaruh dan berhubungan karena pengetahuan dan keterampilan metakognitif akan menstimulus cara berpikir dan pemahaman akan gagasan dalam pemecahan masalah.

Bimbingan orangtua juga berkorelasi positif dengan persepsi siswa tentang kesehatan reproduksi, tetapi berbalik dengan bimbingan guru. Nursal (2008) menemukan dalam sebuah penelitian yang dilakukan, salah satu faktor penting adalah hubungan perilaku seksual dengan pengasuhan orang tua. Bimbingan orang tua adalah segala bentuk dan proses interaksi yang terjadi antara orang tua dan anak-anak dalam suatu keluarga tertentu yang akan memberikan efek perkembangan kepribadian anak (Baumrind, 2004). Temuan ini berbeda dengan penelitian yang dilakukan oleh Liang (2010) sekitar 35,0\% dari siswa mengungkapkan bahwa guru sebagai sumber utama bagi siswa untuk mendapatkan informasi tentang isu-isu kesehatan seksual. Sebuah studi dari Richards (2013) menunjukkan hubungan antara orangtua dan anak adalah salah satu hubungan terpanjang dan paling berpengaruh dalam kehidupan individu dan orang tua memiliki kemampuan untuk mempengaruhi keputusan seksual dan sikap dikemudian hari.

\section{KESIMPULAN}

Berdasarkan hasil-hasil penelitian dan pengujian analisis data, maka dapat diambil beberapa simpulan sebagai berikut: Ada hubungan positif antara tingkat pengetahuan metakognitif, keterampilan metakognitif, kemampuan berpikir kritis, bimbingan orang tua dan guru sangat berhubungan dengan persepsi perilaku seksual siswwa. Hal ini diartikan bahwa 
persepsi perilaku seksual di kalangan siswa SMA di Medan masih terkendali, dan tidak ada perbedaan yang signifikan antara persepsi perilaku siswa di kota dan pinggiran kota medan meskipun masih ada perilaku seks menyimpang. Temuan penelitian ini menyiratkan perlunya informasi yang mendalam dan komunikasi tentang kesehatan reproduksi kepada siswa oleh guru dan orang tua saat di sekolah dan di rumah yang harus lebih ditingkatkan.

\section{DAFTAR PUSTAKA}

Ali, M., Asrori, M. (2011). Psikologi Remaja. Jakarta: PT. Bumi Aksara.

Aspy, C., Vesely, S., Oman, R., Rodine, S., Marshall, L \& McLeroy, K. (2007). Parental Communication and Youth Sexual Behavior. Journal of Adolescence, 30, 449-466. doi: 10.1016/j.adolescence.2006.04.007.

Bahri, S., Apriani, E. (2008). Peran Pengetahuan Awal , Strategi Kognitif dan Metakognitif terhadap Pencapaian Hasil Belajar IPA. Jurnal pendidikan serambi ilmu, Vo. 6. No 1.

Baumrind, D. (2004).The influence of parenting style on adolescent competence and substance use. Journal of Early Adolescent, 11(1), 56- 95.

Dhanapala, K. (2010). Sri Lankan University Students, metacognitive Awarness of 12 Reading Strategies. Journalof International Development and Cooperation, Vol 16, no 1, pp 65-82.

Fisher, A. (2009). Berpikir Kritis; Sebuah Penghantar. Jakarta ; Erlangga.

Flavell, J.H. (1979). Metacognition and Cognitive Monitoring: A new area of psychological inquiry. American Psychologist, 34, 906- 911.

Liang, Chung, H. (2010). Teachers' and pupils' perceptions of sex education in Taiwan and England: a comparative study. $\mathrm{PhD}$ thesis, University of Warwick.

Ikayanti, S. Sugiarto B. (2012). The Influence of Metacognitive Knowledge to Student Learning Out Comes On Salt Hydrolysis Matter in XI Science 4 RSBI SMAN Mojoagung Jombang. Unesa Journal of Chemical Education. Vol. 1, No. 1, pp. 204211.

Kurniawan, T. (2008). Faktor-Faktor yang Berpengaruh Terhadap Praktek Kesehatan Reproduksi Remaja di SMA Negeri 1
Purbalingga. Tesis. Semarang: Program Pascasarjana Universitas Diponegoro.

Kusmiran, E. (2011). Kesehatan Reproduksi Remaja dan Wanita. Jakarta: Penerbit Salemba Medika.

McCulley, E. (2010). A Qualitative Study of Metacognitive Characteristics of Low-Performing Middle School Reading Students. Thesis. Texas State University-San Marcos.

Miranda, Yula. (2010). Dampak Pembelajaran Metakognitif Dengan Strategi Kognitif Terhadap Kemampuan Metakognitif Siswa dalam Mata Pelajaran Biologi di SMA Negeri Palangka Raya. Jurnal Penelitian Kependidikan, (online), TH. 20 No. 2.

Muspiroh, N. (2007). Pendidikan Reproduksi Bagi Remaja. Jurnal Al-Tarbiyah. Vol XX. No 22.

Mkumbo, K. \& Tungaraza, F. D. (2007). Parents' views and attitudes towards school based sex and relationships education in rural and urban Tanzania. Papers in Education and Development, 27, 171-188. Dar es Salaam: DUP.

Miyakado, P.B., (2013). Attitudes and Views of Teachers Towards Students' Sexual Relationship in Secondary Schools in Tanzania. Part I: Social Sciences and Humanities, 4 (1). University Dar es Salaam.

Mnguni, L., Abrie, M., \& Ebersohn, L. (2015). The Relationship Between Scientific Knowledge and Behaviour: An HIV/AIDS Case. Journal of Biological Education, doi: 10.1080/00219266.2015.1007888.

Morawska, A.,Walsh, A.,Grabski, M., \& Fletcher, R. (2015). Parental confidence and preferences for communicating with their child about sexuality. The Journal of Sex Education: Sexuality, Society and Learning, 15 (3). doi: 10.1080/14681811.2014.996213

Nursal, DGA. (2008). Faktor-faktor yang Berhubungan dengan Perilaku Seksual Murid SMU Negeri di Kota Padang Tahun 2007. Jurnal Kesehatan Masyarakat, 2 (2), 175 18.

Raza, S., Adil, A., \& Ghayas, S. (2008). Impact of Parental Death on Adolescents' Psychosocial Functioning. Journal of Psychology, 3 (1), 1-11.

Richards, Nicole M., (2013). Parental Care, Control, and Communication About Sex: The Relation to Risky Sexual Behaviors and Relationship Style in Emerging Adults. Senior Honors Theses. Paper 345.

Salam, A. (2004). Metacognition and Reading Comprehension: Current Trends in Theory and 
Research. Faculty of Education. Suez Canal University.

Santrock. (2008). EducationalPsychology (3rded.). NY: MacGraw Hill.

Sarwono, S. (2011). Psikologi Remaja. Jakarta: Raja Grafindo Persada.
Slavin, R.E. (2008). Educational Psychology: Theory and Practice. Boston: Pearson Education Inc.

Veenman, M. V. J., Wilhelm, P., \& Beishuizen, J. J. (2004). The relation between intellectual and metacognitive skills from a developmental perspective. Learning and Instruction, 14, 89-109, doi:10.1016/ j.learninstruc.2003.10.004 